\title{
Rising Nationalism in the Balkans
}

Fejzi LILA

$\mathrm{PhD}$ candidate, European University of Tirana, Albania

\begin{abstract}
Balkans consists of the geographic and demographic diversity of the complex, with division of the region into new states, with local antagonisms. Balkan leaders, the Great Powers would urge the expansion of national states where and when he wanted interest and would not ignore claims it was one nation over another. The process of developing the nationalist movements and the state - forming in the Balkans, starting with the Patriarchies autonomous movements within the Ottoman Empire, involves the movement of Serbs, Greeks, Bulgarians, Romanians and Albanians. The fall of Bonaparte in 1815, was accompanied by significant changes in Europe in the system of international relations, the diplomacy of the Great Powers. Europe was thrown into the system the concert of Europe, after that of Vienna, while the Ottoman Empire was beginning its stagnation, other European powers had begun to feel the threat of Russia's interests in the Middle East. During this period of time the nationalist movement took place in the region. The nationalism confronted Concert of Vienna principles provoking the First World War.
\end{abstract}

Keywords: Balkans, Concert of Europe, Great Powers, nationalism, Ottomans, Russian.

\section{Introduction}

The fall of Bonaparte in 1815, was accompanied by significant changes in Europe in the system of international relations, the diplomacy of the Great Powers. Europe was thrown into the system the concert of Europe, after that of Vienna, while the Ottoman Empire was beginning its stagnation, other European powers had begun to feel the threat of Russia's interests in the Middle East ${ }^{1}$. Central and Eastern Europe the movement was preceded regenerative process of creating national states, and the Balkans will begin its revival later key, but a dynamic renaissance, tough and full of crisis, known as East crisis. Strengthening Russia, the fall of the Ottomans, the union of Germany and Italy would disturb the overall political situation on the continent and in the world transformed by "The Concert" Vienna in a "Funeral" universal.

After the expulsion from Germany, New Empire Austro-Hungarian had nowhere to lay except Balkans. Since Austria did not participate in overseas colonization, its leaders saw Balkans with its slave population as a natural arena for its geopolitical ambitions - even she walked along other Great Powers. With such a policy, the conflict with Russia was natural.

Balkans consists of the geographic and demographic diversity of the complex, with division of the region into new states, with local antagonisms. Balkan leaders, the Great Powers would urge the expansion of national states where and when he wanted interest and would not ignore claims it was one nation over another ${ }^{2}$. The process of developing the nationalist movements and the state - forming in the Balkans, starting with the Patriarchies autonomous movements within the Ottoman Empire, involves the movement of Serbs, Greeks, Bulgarians, Romanians and Albanians.

Until then many ways, much effort enlightenment, political, military and diplomatic people would need for the establishment of its independent state. Archival sources, copyright and publicity of the time argued that the Albanians were omnipresent, initially they warned these processes indepedents in Patriarchy of loannina, still were in solidarity with the Serbs against

\footnotetext{
${ }^{1}$ Norman Rich: "Diplomacia e Fuqive të Mëdha 1814-1914", Tiranë, Toena 2006, ISBN: 99943-1-199-9, Fq 46

2 M Glenny: "Histori e Ballkanit, 1804-1999, Nacionalizmi, Luftërat dhe Fuqitë e Mëdha", Tiranë, Toena 2007, ISBN: 97899943-1-231-3, fq 133
} 
the Ottomans, supported the Greek revolution for independence and any move to serve creation national states against the Ottoman Empire in decline.

The nineteenth-century has been the most dynamic in the political history of the Balkan peoples, as well as other peoples were Russians, Italians and Germans. This century was characterized by aristocratic philosophy, conservative and aimed to preserve at all costs stagnation, not agree with the political changes. Moment of involvement of the Ottoman Empire under the multilateral system from Continental transformed European international system, for the scope and structure of the Ottoman Empire.

Vienna concert was accompanied by the political dynamic movement from below and three very large and powerful: liberalization, nationalist and imperialist state building. The formation of two large states unitarist power of imperialist ambitions International, Italy and Germany, the disclosure of interests imperial Russia in the international arena as well as the clash of powers for markets, raw materials and areas influential international players were indicators of movements in the Balkans including statehood nationalist movements against the Ottoman Empire. In this process for political reasons, he merges the deep and Russia, although it was not part of the Balkan geopolitical, based on interests and anti-Ottoman imperial and justified on grounds of racism and religious bigotry.

Various authors prove that Albanians from the people in solidarity with the people of the small neighboring their wars for independence, were gradually closing, and neutral only when the region began to emerge interests clientele Russian, which at any time and in any circumstance they left the Albanians and their interests outside attention. Bismarck wanted a Balkansharing agreement between Austria and Russia, but it never materialized division. Austrian leaders feared any visible anger of Russian power in the Balkans and the Hungarians did not like the prospect of including more habzburgase Slav empire, because it would reduce their importance ${ }^{1}$.

Rise of Russia became the Slavic clientele base - religious, supporting mainly the southern Slavic peoples and the same confession. Rus involved in this project mainly Slavs, while the Greeks somewhat farther. Russian project was in Serb yearning directed against the Albanian coast, the Adriatic Sea... At the time of her first liberation from Turkish rule targets a Serbia did not cease for a free outlet to the sea². Albanian people was the more burning in the Balkans who was coming in the front yard of European empire of Peter the Great.

Russian project for the Balkans in mind the Albanians, who were not related Slavic nor a confession were fully. Analyzing the Russian attitude towards Albanians, British researcher Edit Durham states: "Albania is faced with another greatest enemy was Russia. Later will become clear determination of Slavs and orthodox in the Peninsula and any other condition will not be tolerated "3, "... the attention was directed first of all on the coast of Albania"4.

Dynamics and complexity of the political developments in the nineteenth-century, wrapped-constituent nationalism, liberalism and imperialism-monarchist to colonial rivalries. European concert separation phenomena pose difficulties, events, movements, periods, and of course the results factors. Balkans has been very hot and involved in these dynamics. The phenomenon remains typical Balkan ethnic diversity, religious, geopolitical. This diversity of alliances gradually transformed understanding many centuries under the Ottoman Empire into a problem, conflict and war between the Balkan people for a very long period.

Roman doctrine based on "divide et impera", Byzantium survived for 10 centuries, France's Cardinal Richelieu for 30 years held the chopped weaker German princes. This doctrine was used by the Ottomans, Tsarist Russians, Austro-Hungary from England to take European initiatives against Bonaparte's France and Hitler's Germany's Kaiser.

Researchers widely agree that the Patriarchy of loannina, established, strengthened and expanded by Ali Pasha have been initiating factors, incentive, inspirational, supportive and inclusive in a way, of the Balkan peoples in nationalist state-building processes.

\footnotetext{
${ }^{1}$ Norman Rich: "Diplomacia e Fuqive të Mëdha 1814 - 1914", Tiranë, Toena 2006, ISBN: 99943-1-199-9, fq 229

2 Sergej Dmitrieviç Sazonov: "Kujtime", Tiranë, Helga's Secret, ISBN: 978-9928-4022-8-8, fq 99

${ }^{3}$ E. Durham, "Twenty Years of Ballkan Tangle", page 100

${ }^{4}$ Sergej Dmitrieviç Sazonov: "Kujtime”, Tiranë, Helga's Secret, ISBN: 978-9928-4022-8-8, fq 100
} 
Balkan doctrines, "Megali Idea" and "Naçetania" first inspired to other Germans to the French. Megali Idea was inspired by German Volksgeist theory connecting with ancient historical memories of Byzantium, while Serbs joined the French unitary vision Slavic solidarity, by molding both the "Great Project", the "Naçertanie".

Naum Veqilharxhi in 1846 in a paper written in Greek encyclopedic expressed; "Patriots! Yes I advise co-patriots our who love the homeland, to scrutinize a new study philology, which was written and published by Greek newspapers as an act that deserves global attention, more so since it has about Albanians"1.

Greek nationalism was based on religion and not the nation as identity. Here he was rooted Byzantinist doctrine of neoGreek nationalism in the early-nineteenth century. This doctrine called "Megali Idea" stood on the foundation of nationalism and Greek foreign policy. "Megali Idea", from its birth to the 1854 strategy aimed at rebuilding the whole Byzantine political space within the new Greek state. Connecting basis, according to the "Megali Idea" stood on religion, then the orthodoxy.

According to Greek strategy, all Orthodox people, once under the Byzantine Empire, now needed to be included in the territory under the sovereignty and political borders of the modern Greek nation-state. Hellenic identity and Byzantium were asymmetrical space and began to disclose all its problems with the Orthodox people, but not Hellenistic, especially with the people of the Balkans with the Orthodox religion, but with different identity.

This asymmetry "Megali Idea" initially faced with Serbs in the Balkans. As a result of the politicization of history and illinformed, Greek-Serbian regarded as have always been excellent and directed against the Albanians and other peoples in the Balkans, but different scholars of the period of raising nationalism in the Balkans and the Crisis they have argued that the first East "Megali idea", as foreign policy Hellenic fought Serbian politics. After the Russo-Turkish War in the years 1861-1867, between Greeks and Serbs were deep discrepancies regarding their visions of political positions in the Balkans².

For a period of approximately seven years, the Greeks and the Serbs had talks were not easy to determine the position after the Russo-Turkish war. Greek scholar, Kofos Greek-Serbian talks defines the years 1861-1867 "for the completion of the alliance against Turkey in order to liberate their compatriots and to share the Balkan Peninsula"3.

The process of the Greek-Serbian talks during this period led to the signing of an agreement negotiated between them. Lengthy negotiations with substantial crash were able to complete the deal after the second round of Greek-Serbian negotiations, precisely in 1867, in Vëslau near Vienna. Greek-Serbian agreement dated August 14-26 1867.

Albania and Albanians in the Balkan positions have been at the center of the Serbian-Greek talks. Studies show that at this point had no misunderstanding sides of inconsistency. This is the moment when connecting alliance undeclared GreekSerbian against the Albanian factor in the Balkans, which recently show that this alliance will once again sit down times will up, time will unfold open again in secret, but nevertheless will continue to in recent times ${ }^{4}$. On the allocation of land to the Greek-Albanian population Serb compliance was complete, while negotiations on dividing Turkey's European lands were characterized by many divergences between the parties.

Greek considered strategy in southern province of Balkan mountain ranges as inhabited only by Greeks forcibly assimilate and Hellenized Slavs. So "Megali Idea" regarded these people as an integral part of Greek civilization. As part of this civilization, "Megali Idea" of the people involved in the former Byzantine map, and consequently on the map of Greece drafted the new policy. Politically, Greek diplomacy feared the expansion of the south Slav element in the Balkan Peninsula ${ }^{5}$.

Serbian Ekspasioni is earlier than "Big Project" llia Grashaninit and that "migration of Arnaut", "The problem of national minorities in Yugoslavia" New Vaso Cubrilovic, 1937 and the memorandum "Manu". Circa 1836-1837 have close cooperation between Belgrade and Croatia llirjana Movement. Patriots "Yugoslav" Serbian territories counted separately Naçetania included in Srem, Backen, Banat, which should secede Hamburg when Serbia to join the Croatian territories and

\footnotetext{
452-13-7, fq 117

2 Studime Historike, Nr. 1, vëllimi XXXI (XIV), Akademia e Shkencave, Tiranë 1977, faqe 176

${ }^{3}$ E. Kofos, Greece and Eastern Crisis 1875-1878, Thesaloniki, 1975, page 21

${ }^{4}$ L Bashkurti: "Çamëria", Tiranë, Geer 2012, ISBN: 978-9928-105-18-9, fq 137

${ }^{5}$ Studime Historike, Nr. 1, vëllimi XXXI (XIV), Akademia e Shkencave, Tiranë 1977, faqe 176
}

1 Blakaj S \& Ismaili I; "Letwërkëmbime të Rilindjes Kombëtare Shqiptare". Prishtinë: ARBI Ltd; New York: Vatra, 2014, ISBN: 978-9951- 
Montenegro. Serbian Imbalances calculation of the Habsburg empire, was returned "Naçetanian" towards the Ottoman territories. Strategy "Naçertania" Garashaninit aim of forming a great Yugoslav state, the composition of which will be included Bulgaria. "Naçertania" long work and sacrifice for Bulgarian renaissance for this.

Grashanini llia emphasized the unity of Serbs with those of Montenegro and the Ottoman territories in Bosnia and Herzegovina, which would allow the Principality have cruise, were called to help Dusan memories of the Empire in the first century. XVI, while romantic historicism, combined with ideas jakobiane gave Serbia until 1914 a foreign policy program 1 . Also, the Serbian foreign policy strategy afraid of Hellenistic neo-Byzantine "Megali Idea", because, according to Serbs, a nation so great Panhellenic would seriously undermine the balance in the Balkan Peninsula and would be the cause for conflicts of interest. Russia originally had inspired financed itself "Megali Idea" and Naçertanien as doctrine and political movement allied anti-Ottoman, but after breaking Ottoman control his will to establish a stable regional situation with Russian influence.

At this time the Russian influence in the Balkans, relative to other powers, had an impact even greater due primarily to religious Greeks and the Slavs of the south due largely racial. Tsarist Russia religion and race were essential components geopolitics. Under the influence of the Russian care of the other European powers, Serbs and Greeks after disagreements about the allocation of spaces Ottomans in the Balkans European and agreed to fight side by side against the Ottoman Empire $^{2}$ and a division between them. Serbia will invade and annex Bosnia-Herzegovina, Albania North, including Durres, Elbasan, Ohrid and territories in the north of the Balkan Mountain Range. While Greece to annex the provinces in the south of the Balkan Mountain Range, Thessaly, Macedonia, Thrace and Albania up to half of Durres. It was clear, that the schedule bilateral Serbian-Greek, Albania and Albanians divided in half between them³ .

Serbian war - Turkish 1876 was a defeat for Serbia but she realized part of its objectives, the Treaty of Berlin gave Toplicën and Vranje, Muslim Albanians were expelled from their lands and legitimize ethnic cleansing and religious conducted by the Balkan countries such as Bulgaria, Serbia, Greece and Montenegro 4 . In the first decade of the 19th century Serbian government abandoned the policy of rapprochement with the High and konkretizoi agreement with Bulgaria and Montenegro on the principle "the Balkans, states Ballanit", which will keep united Slavic countries - the Balkans. These strategies were bisedimee agreement signed away any secrets and information for Albanians.

"Megali Idea" was the strategy of Greek foreign policy before and throughout the Eastern Crisis. Serbian pact - Greek for sharing the spoils of war were hit by the treaty that accompanied St. Stephen. Confusion and frustration in Greek politics led to crash out of the "Megali Idea" in asymmetry with geopolitical terrain of the Balkan Eastern Europeans. Greek diplomacy in this situation openly reacted run ambassador to Istanbul. In the memorandum stated that "the Greek nation undivided stretch of the Adriatic Sea to the Black Sea... During these three years, the Greek national aspirations often ignored by international conferences and Hellenism was approaching catastrophe. However, due to the strange turn of events, catastrophic aspect disappeared and gave hope to realize not only limited political goals of the Kingdom of Greece, but also the hope of realizing the dreams of the Greeks centuries" 5 .

Greek diplomacy had managed to understand that Russia had done as a priority choice of South Slavs in Serbia at the top, before the Greeks. Greek reflection brought Greek diplomatic move by Russia to the prioritization of the Treaty of San Stefano to England as a guiding force post - Ottoman. These reasons show that the doctrine of "Megali Idea" was beginning its wrinkling. It was essentially a reactionary doctrine, the doctrine of historical determinism and religious determination on national and cultural identities. Hitting her final "Megali Idea" will suffer in the failed attempt to annexation of Asia Minor in 1922, which would cause the Greek people the greatest loss in the history of modern and with the burial of the doctrine of "Megali Idea"6.

\footnotetext{
1 Georges Castellan: "Histori e Ballkanit", Tiranë, Çabej 1991, fq 324-326

${ }^{2}$ Po aty, fq 327

${ }^{3}$ L Bashkurti: "Çamëria", Tiranë, Geer 2012, ISBN: 978-9928-105-18-9, fq 139

${ }^{4}$ Xhafer Sadiku: "Shqipëria 1878-1928, Roli i Elitës Politike", Tiranë, Mirgeerald 2014, ISBN: 978-9928-07-257-3, fq 33

${ }^{5}$ E. Kofos, Greece and Eastern Crisis 1875-1878, Thesaloniki, 1975, page 17

${ }^{6}$ Studime Historike, Nr. 1, vëllimi XXXI (XIV), Akademia e Shkencave, Tiranë 1977, faqe 176
} 
In all these politico - diplomatic manipulation relating to the Eastern Crisis, Albanians were kept away. Their neutrality in the Russo-Ottoman renamed Force and then by some Greeks as Serbs from Albanians otomanist attitude, while the Albanians continued to contribute to other people in the East as were Romanians and Italians in the West.

Before the crisis of 1875-1878, the Greeks had created a diplomatic mindset owner of widespread idea of Greek circles that "these two people closely connected through their historical experience, forced to form in one way or another a unified state"1. This opinion Greek diplomacy tried to reveal the diplomacy of the Great Powers, but by Albanian researchers, the explanation was inconsistent.

In the thesis of "Megali Idea" priority argumentative held orthodox religion, neo-bizantinizmit and not the language, but when it came to the unification of Albanians in one state with Greeks, priority held two-linguistics, which according to the Greeks was on the Albanian population and ignore religion at all. This was the contradiction and jorealizëm the doctrine of "Megali Idea" and one of the causes of the shrinking and its historic failure.

While diplomacy conspiracy went against the interests of the Albanians, the Albanian national movement rose with powerful dynamics. Albanian Diaspora in major centers like arberesh Italy, Albanians Bucharest intellectuals of Istanbul and many other centers show that the Albanian national movement is slowly and distinctly contoured. To the great powers of the time and neighbors Albanians, Greeks, Serbs, Albanian national movement constituted a real and growing concern.

\section{References:}

[1] Norman Rich: "Diplomacia e Fuqive të Mëdha 1814-1914”, Tiranë, Toena 2006, ISBN: 99943-1-199-9, Fq 46

[2] M Glenny: "Histori e Ballkanit, 1804-1999, Nacionalizmi, Luftërat dhe Fuqitë e Mëdha", Tiranë, Toena 2007, ISBN: 97899943-1-231-3, fq 133

[3] Sergej Dmitrieviç Sazonov: "Kujtime", Tiranë, Helga's Secret, ISBN: 978-9928-4022-8-8, fq 99

[4] E. Durham, "Twenty Years of Ballkan Tangle", page 100

[5] Blakaj S \& Ismaili I; "Letërkëmbime tw Rilindjes Kombëtare Shqiptare". Prishtinë: ARBI Ltd; New York: Vatra, 2014, ISBN: 978-9951-452-13-7, fq 117

[6] Studime Historike, Nr. 1, vëllimi XXXI (XIV), Akademia e Shkencave, Tiranë 1977

[7] L Bashkurti: "Çamëria", Tiranë, Geer 2012, ISBN: 978-9928-105-18-9

[8] Georges Castellan: "Histori e Ballkanit", Tiranë, Çabej 1991

[9] L Bashkurti: "Çamëria”, Tiranë, Geer 2012, ISBN: 978-9928-105-18-9

[10] Xhafer Sadiku: "Shqipëria 1878-1928, Roli i Elitwës Politike", Tiranë, Mirgeerald 2014, ISBN: 978-9928-07-2573

[11] Studime Historike, Nr. 1, vëllimi XXXII (XIIV), Akademia e Shkencave, Tiranë 1977

${ }^{1}$ E. Kofos, Greece and Eastern Crisis 1875-1878, Thesaloniki, 1975, page 24 